\title{
THE PARTY'S OVER? THE ANGRY BRIGADE, THE \\ COUNTERCULTURE, AND THE BRITISH NEW LEFT,
}

$1967-72$

\author{
J.D. TAYLOR \\ University of Roehampton
}

ABSTRACT: This article analyses the emergence of politically-motivated acts of leftwing terrorism in Britain between 1967 and 1972. Through the case of the 'Angry Brigade', an ill-defined grouping which claimed responsibility for a number of attacks against property between 1970 and 1971, it analyses how protest and political violence emerged from discourses and events in the British New Left, the anti-war protest movements, the counterculture, and the underground press. Against common interpretations of '68 as a watershed of naïve hopes that waned into inaction, this article presents a consistency of political activity that developed beyond traditional party and class politics towards a more internationally aware and diverse network of struggles for civil equality. Among the shared political and cultural commitments of the counterculture, campaigns around squatting, women's liberation, or the necessity of 'armed propaganda' each became possible and at times overlapped. Through the development, actions, communications, surrounding media discourses, police investigation and criminal trials of ten individuals for involvement in the Angry Brigade as a brief-lived axis of these overlapping points, it relocates their neglected historical 
significance among the wider political militancy of the late 1960s to early 1970s, and accounts for their lack of popular support and obscurity since.

Social histories of the 'Swinging Sixties' in Britain have tended to reinforce an impression of untrammelled optimism, peace, prosperity and fun. ${ }^{1}$ Compared to the miners' strikes, IRA attacks and 'lights going out' that characterize popular assays on the less swinging Seventies, historians have tended to take on face value Harold Wilson's bold 1963 vision of a modern Britain 'forged in the white heat of this [scientific] revolution'. ${ }^{2}$ Jonathon Green describes its 'glorious mêlée' of creativity and hope, and Tariq Ali notes its unique 'generosity of spirit', as if this youthful joy ceased a little after New Year's Eve, 1969. ${ }^{3}$ Obscured from these accounts are the discourses and events of political violence that emerged across the networks of radicalized students, anti-war protesters, the underground press, the counterculture, and the British New Left. This article seeks to restore the significance of this problem of political violence, and its place in the wider histories of the British counterculture and New Left, through the case of 'the Angry Brigade', an ill-defined grouping which claimed responsibility or connection to around twenty six terrorist attacks against property between 1970 and 1971. ${ }^{4}$ The nature and purpose of these attacks against high-profile targets, ranging from government ministers, police, industrial disputes, the Spanish government, and the Miss World 1970 contest, has been largely erased from popular histories of the period. ${ }^{5}$ Marwick gives one dismissive mention in his magisterial The Sixties, and they have no mention in the social or political histories of this period by Beckett, Black, Clarke, 
Morgan, Porter, or White. ${ }^{6}$ Where discussion occurs, they become magnified into either a romantic or mysterious anomaly. ${ }^{7}$

Neither approach sufficiently captures the wider problem of political violence in Britain during this period, of the 120 recorded left-wing attacks against property that occurred between 1969 and 1972, and which overlap with the rise of more lethal Irish republican terrorism that begins with the Official IRA's Aldershot barracks bombing on 22 February 1972, and followed by a devastating campaign by the Provisional IRA from March $1973 .{ }^{8}$ The very few histories of the Angry Brigade also tend to take for granted that the five individuals prosecuted for 'conspiracy to cause explosions' across two high-profile trials (Jake Prescott on 1 December 1971; John Barker, Hilary Creek, Jim Greenfield and Anna Mendleson on 6 December 1972) were actually those who planted explosives or fired weapons at political targets - a charge that no individual was ever found guilty of. Even within radical histories of the Left, the 'Angries' remain obscure, and any claim of membership of the Angry Brigade remains tenuous and legally undetermined.

As Varon and Christiansen argue, discussions of armed political opposition in New Left commentaries tend to dismiss it as either an aberration or a fringe phenomenon, thereby obscuring the wider discussions of violence as a political strategy at this time in the underground press. ${ }^{9}$ Whilst I reject the interpretations of Christiansen and Robinson that the Angry Brigade reflected the wider political interests of the counterculture as a whole,${ }^{10}$ their communications and targets present a useful case in which to assess wider overlapping problems and themes. The unique nature of these political discourses and activities also provides a valuable opportunity to explore the 
growth of the New Left; the 'watershed' moment of the second anti-Vietnam war protest in London of October 1968; ${ }^{11}$ and the now-obscured growth of violence and repression among and against the counterculture.

It also enables a historical reappraisal of the political commitments beneath 'dropping out' from university education into the counterculture (and the kind of post1963 education system that made this possible), which often led as much to experimentation with communal living and recreational drug-taking as it did to radical community activism. Through examining the self-identifying fourteen communiqués of the Angry Brigade, alongside the backgrounds of those individuals later charged for their involvement, the article intends to demonstrate the overlapping strands of New Left political discourse, countercultural lifestyles, the influence of French Situationist texts, a growing interest in community struggles around squatting, welfare claimants and legal aid, and the broader development of new social movements around identity that would continue during the 1970s - of which the 'Angry Brigade' formed a brieflived axis.

The unclaimed legacy of the Angry Brigade, dismissed as either naïve or genuinely dangerous by contemporaries, will form the basis of a conclusion which relocates their historical significance and makes the case for reappraising the wider political militancy of the late 1960 s to early 1970 s. It draws on a wider range of archival and print sources than considered by previous historians of this period to recontextualise the Angry Brigade within the emergence of the New Left and counterculture primarily in Britain, though indicating its international links. The focus of its analysis is historical rather than historiographical: wider questions about what is 
included in the 'Sixties', or the relationship between evidence available and arguments established have been avoided for the sake of concision or else discussed where they relate to a specific source. Whether the trial and prosecution of five individuals for conspiracy to cause the Angry Brigade-claimed terrorist attacks marked the 'end of the party', in the senses of both the jubilant optimism of the Sixties and a commitment to alternative non-political party social movements, will be the subject of the conclusion.

To adequately contextualize left-wing political discourses and protest movements between 1967 and 1972, the milieu of the counterculture and the Angry Brigade, I will first define and examine the growth of the 'New Left' in Britain. Staunchly anti-war in outlook and broadly socialist in its politics, the New Left coalesced from November 1956, following the Soviet Union's violent repression of the Hungarian popular uprising, alongside the contemporaneous invasion of the Suez Canal by France and Britain. ${ }^{12}$ The former event, and the subsequent refusal of other national communist parties to distance themselves from it, alienated many western Marxists, already disorientated by Khrushchev's admission of Stalin's atrocities as head of the USSR. Suez was also a timely reminder that despite a post-war commitment to decolonization, western imperial ambitions were still disrupting the interests of popular democratic movements internationally. Members of the Communist Party of Great Britain's Historians Group began to doubt the credibility of the Soviet Union in furthering any kind of recognisable Marxist politics. Historians like E.P. Thompson, John Saville and Raphael Samuel left the group in 1956 and became involved in what would become 
known as the 'New Left', a term taken from the 'Nouvelle Gauche' in France, an independent and internationalist 'third position' developed on the pages of France Observateur that sought to distance itself from the two dominant Left positions of Stalinism or social democracy. ${ }^{13}$ A relatively heterogeneous British New Left first clustered around the New Reasoner newspaper, formed by John Saville and E.P. Thompson in 1957, and the Universities and Left Review, formed by ex-party members Gabriel Pearson and Raphael Samuel, alongside non-Party members Charles Taylor and Stuart Hall. Its more cohesive movement would properly begin in the debates of the New Left Review (NLR), formed from a merger of these two publications in $1960 .{ }^{14}$ With its departure from Stalinism and the Soviet Union as the model for proletarian revolution, writers on the NLR reported favourably on new sites of popular revolution, from China and Cuba to Vietnam, and attempted to develop what E.P. Thompson called a 'socialist humanism' through a synthesis of social and cultural studies. ${ }^{15}$ Members of the New Left also became active in groups like the Campaign for Nuclear Disarmament (CND), as well as participating in civil rights movements in England, the United States, and Northern Ireland. ${ }^{16}$ From a more traditional 'Old Left' model based on a homogeneous class led by a single national party, the New Left were interested in a diffuse network of struggles around political equality and freedom. Civil rights, a resurgent feminism, and gay and lesbian struggles would become important, as did the politicisation of more quotidian issues like housing, welfare, and equal pay for men and women.

The NLR developed a more intellectual criticism of society and politics that addressed a generation of younger people and student struggles. It was reflected in the 
increasingly theoretical content of the NLR, marking a significant change of audience to orthodox Marxism, which had traditionally aimed to spur the industrial working-class into revolutionary action. This new courting of a student readership, coupled with a new international outlook following Perry Anderson's rise to the editorship of the NLR in 1962 (and an 'end' to this first mutation of the New Left), informed a new student militancy that was beginning to occur on British university campuses from $1967 .{ }^{17}$ Herbert Marcuse supplied the notion of 'Student Power', which the NLR tried to foment with their call to establish 'red bases' in universities, a movement considered by others in the counterculture as hopelessly out of touch. ${ }^{18}$ For many, it was the protest movement against the Vietnam War that concentrated these animated energies and initiated them into a coherent struggle. ${ }^{19}$ Dissatisfaction would ultimately grow with the myriad New Left groups and their schisms, but from this brief outline one ascertains the distinctly international, democratic, and participatory foci that became prominent in New Left discourses towards the latter part of the 1960s. A genuine sense of camaraderie and shared oppression was felt by protesting students in England with the civil rights movements first for black Americans, and later in Northern Ireland; the growth of feminism; gay rights movements; and the struggles for national selfdetermination in Cuba, Vietnam, and elsewhere. ${ }^{20}$ As student movements expanded their militancy against wider class-based structures of society in general by 1968, particularly in France, the United States, West Germany, and in Britain, their political radicalism was informed by those New Left discussions from the previous decade. 
There is a shared sense of 'generation' in popular culture, music and political discourses during the mid-sixties, with an implied commitment to a political stewardship that would avoid the mistakes of the previous generation that led to the Second World War. The 1962 Port Huron statement of the American Students for a Democratic Society (SDS) indicates this kind of thinking: 'We are people of this generation, bred in at least modest comfort, housed now in universities, looking uncomfortably to the world we inherit. ${ }^{21}$ Although the new student protest movements and the New Left would crystallise around opposition to the Vietnam war and the perceived complicity of the British government, students were also engaged in their own struggles about this uncomfortably inherited world, from greater representation and democracy within universities, to a swelling number 'dropping out' from their courses in rejection of what were judged the confining structures, class hierarchies, and sexual repressions of bourgeois society. ${ }^{22}$ The major expansion of free higher education following the 1963 Lord Robbins report facilitated a more extensive education of the 'baby-boomers', with new universities and polytechnics built nationwide. ${ }^{23}$ It became possible for a new generation of students from working-class backgrounds to attend university, like John Barker, Anna Mendleson and Jim Greenfield. ${ }^{24}$ Among this self-aware 'generation', increasingly international and self-reflective in its political commitments, emerged a shared sense of culture, or counterculture, which defined the political commitments and identities of many students.

During the 1960s, a unisex fashion for long hair, liberal personal views, folk and rock music, and a rejection of mainstream society fell under the "hippie" label, popularised by a Time magazine article of July $1967 .{ }^{25}$ Timothy Leary's call to 'turn on, 
tune in, drop out' of mainstream society, with the aid of psychedelics, was reproduced across the underground press and indicated the more introspective if hedonistic nature of hippie. ${ }^{26}$ London was one of the major centres of hippie culture, with events like the 'Dialectics of Liberation' conference at the Roundhouse in July 1967, bringing together anti-psychiatry (R.D Laing), black civil rights (Stokely Carmichael), Marxist theory (Marcuse, and Ernest Mandel) and beat poetry (Allen Ginsberg) in one 'intellectual bein', reflecting diverse overlapping interests among the counterculture and the New Left. ${ }^{27}$ Hippie also reflected a wider influence of American popular culture, literature, and music in Britain and elsewhere that this new generation largely took for granted, with little of the interest in Englishness or fears of 'Americanisation' that motivated the 'Angry Young Men' a decade before. ${ }^{28}$ The political protest movements led by students from 1968 led Theodore Roszak to term this a 'counter culture', in opposition to an existentially-impoverished 'technocratic' society. ${ }^{29}$ Roszak's term, soon in vogue, summarized the crossover between alternative lifestyles, an antipathy to work, and the extension of political activity to wider problems of housing, employment, sexuality, and identity more broadly.

Alongside Roszak, a number of other influential works of the time combined Marxist analysis with an existentialism-infused libertarian sociology, like Marcuse's One-Dimensional Man (1964), alongside the works of Erich Fromm, impressing the view that politics was no mere struggle of parties, unions, or classes, but permeated the very basis of social and personal relations. The growing field of Cultural Studies in Britain, pioneered in works by Richard Hoggart, Raymond Williams, and E.P. Thompson, had led to the formation of the Centre for Contemporary Cultural Studies at 
the University of Birmingham in 1964, politicising popular culture through its research. Left-wing ideas had growing prominence in the mainstream media too: Ken Loach's social realist drama Cathy Come Home (1966), highlighted the problems of homelessness and squatting, leading to the formation of charities like Shelter (1966) and Crisis (1967), and later inspiring politicized squatting campaigns like that led by the London Squatters Campaign from 1968 on. ${ }^{30}$ With such inheritance came a new kind of political commitment to libertarian social change that crossed over into lifestyle and identity, as the personal became increasingly political. ${ }^{31}$

\section{III}

From 1964, Harold Wilson's Labour government had overseen a new liberalism in legislation, from decriminalisation of homosexuality and abortion to laws against racial discrimination and equal pay for women in employment. ${ }^{32}$ British society felt more liberated and 'swinging', enjoying the proliferation of consumer commodities and fashions. But Wilson's prior economic goal, to build a modern Britain with social equality through technological revolution, came aground after his re-election in 1966. His government was felt to have mishandled an assault on UK sterling from July 1966 which resulted in a major sterling devaluation by November 1967, matched by a growing balance of payments deficit, and an unpopular policy of wage restraint in the August 1966 Prices and Income Act. ${ }^{33}$ Contrary to election promises, poverty among old people, the disabled, and other disadvantaged groups was starting to increase. ${ }^{34}$ Alongside growing student unrest, industrial strikes were increasing, indicating a growing disillusionment with mainstream Labour party politics. 
Calls for revolution were also heard within the establishment: Cecil King, proprietor of the Daily Mirror, had suggested a coup against Wilson. ${ }^{35}$ His government never recovered from these setbacks. It lost strongholds in Wales and the North over 1968 and 1969, and the lasting failure to reach agreement with the Trades Union Congress over 1969, spectacularly in the rejection of Barbara Castle's In Place of Strife paper, reinforced the impression that Wilson was both ineffective and out of touch with Labour's working class base. ${ }^{36}$

The "surprise" election of Ted Heath's Conservatives in June 1970, with their "Selsdon man" campaign targeting the aspirational working classes, would have further dismayed the politicised counterculture, anxious for a more 'total' political change. As Time Out put it, 'We all know - or rather, experience - the reasons for not using our votes; the big political parties are untruthful and unapproachable, and the whole system of politics seems irrelevant to our lives." ${ }^{, 37}$ Heath's victory also rested on low voter turnout by traditional Labour supporters, for whom Wilson symbolised an increasing lack of credibility in mainstream politics.

Among the New Left, criticism of Wilson had followed accusations of 'complicity' over the Vietnam war (Wilson refused either to denounce the conflict, or commit British troops to it). A broadly New Leftist coalition emerged in the Vietnam Solidarity Campaign (VSC), who organized a number of major protests against the Vietnam War at the US Embassy at Grosvenor Square, London. ${ }^{38}$ Whilst protests had begun in America from around 1964 on, sympathetic demonstrations in London began from October 1965, with escalating attendances and arrests during March and July of 1966. ${ }^{39}$ New forms of protest were developing too that were more extensive and 
disobedient than the more well-behaved form of marches that had typified political protest from Jarrow to the CND. The first British university occupation occurring at the London School of Economics on 13 March 1967, involving over 2,000 students, with another occupation at Hornsey College of Art on 28 May 1968 lasting seven weeks. ${ }^{40}$

The first large-scale protest organized by the VSC occurred on 23 October 1967 and was marked by its unusual violence, after police attempted to prevent 5,000 demonstrators from reaching the American embassy at Grosvenor Square. ${ }^{41}$ Aiming to build on its success, the VSC organized their next march for 17 March 1968. Political violence became increasingly prominent, with violent direct action becoming frequent (and frequently-publicized). Televised news coverage of the unruliness of the protests raised awareness of them, and the underground press would become increasingly revolutionary in its content, such as Oz's "Revolutionary Oz" (January 1968). ${ }^{42}$ As a solidarity movement with the Vietnamese, the rapid military defeats caused by the 'Tet offensive' from January 1968 inspired many to consider American military power as no longer omnipotent. Could a similar victory be achieved by bringing the war home? As Nigel Fountain remembers, many felt a new hope of 'winning' in protest struggles against imperialism. ${ }^{43}$

The 17 March demonstration attracted an even greater number (estimates varying between 25,000 and 80,000 ), with even more violent police clashes, known later as 'the battle of Grosvenor Square'. ${ }^{44}$ Violence was in the air: as Rolling Stones singer Mick Jagger put it in $I T$, 'We're so violent, we're violently frustrated. We haven't got enough violence, we've no opportunity' (the march would later inspire his 'Street Fighting Man', with lyrics posted to Black Dwarf in November following the song's BBC ban). ${ }^{45}$ 
The VSC march seemed to mark for many commentators a change in the political climate. According to the centre-left political magazine New Society,

The demonstration was something new, something that indicates the pattern of major protests we shall have in the future ... things cannot be the same again after Sunday. The time of the orderly peace-platform marchers are gone. ${ }^{46}$

It was a year marked by violence and threatening chaos: within weeks of the assassination of black civil rights leader Martin Luther King Jr., British Conservative politician Enoch Powell made his "Rivers of Blood" speech on 20 April, supported by multiple demonstrations of London dockers, pointing to looming social breakdown as a result of non-white immigration into the UK. ${ }^{47}$ Events in Paris during May seemed to further indicate that western societies were on the cusp of an international, total revolution. $^{48}$

27 October saw a larger but more peaceful and anti-climactic protest: 100,000 VSC-led demonstrators marched towards Hyde Park, with a breakaway group of around 5,000 reaching the US Embassy, but this time repelled by police. ${ }^{49}$ The lasting inconclusiveness of this protest, and the schisms fissuring between organized New Left groups, impressed a mood of defeat and dispersal in late 1968 that would continue across $1969 .{ }^{50}$ For some, like Barker and Mendleson, peaceful marches seemed a deadend, a 'hypnotic, genital urge - a trap', making no difference to the decisions of the establishment. ${ }^{51}$ Later marches against the Embassy in October 1969 and May 1970 saw diminishing attendances. ${ }^{52}$ 
As presented earlier, 1968 felt like a 'watershed' moment to contemporaries, indicating that mass political demonstrations, or transformation through large political parties, had failed to effect any substantial change. During 1969 this pessimism and agitation continued, with no political grouping succeeding in coagulating the diverse political commitments of the counterculture, and internal disputes fracturing smaller parties. ${ }^{53}$ Yet the protests had provided an education in campaigning, civil disobedience and political analysis for many, which would be further explored through the prism of identity. Sheila Rowbotham reflects that the 'boundaries of assumptions about where politics began and ended seemed to have been infinitely extended by the extraordinary happenings of $1968,{ }^{54}$ The revolutionary rhetoric in the underground press continued, with Black Dwarf proclaiming 1969 the "Year of the Militant Woman". Political commitments became increasingly amorphous in the counterculture, with squatting, communal living, and rent strike campaigns developing, as young leftist activists became increasingly discontent with Wilson's beleaguered Labour government and parliamentary politics more broadly. ${ }^{55}$

The personal trajectories of those later prosecuted for their involvement in the Angry Brigade is insightful. At Cambridge University, Barker and Greenfield had organized a 'Campaign Against Assessment', with Barker tearing up his exam papers in June 1969. ${ }^{56}$ Both dropped out, disillusioned with a university education that they felt would train them to exploit the working class, and together moved to London, becoming booksellers at Camden market. ${ }^{57}$ The cold winter that year introduced the two to 
housing and squatting, and they were actively involved in assisting families to squat in east London. Around this time the pair met Mendleson and Creek, who also dropped out of Essex University in 1969 with similar plans. ${ }^{58}$ Now part of a wide, informal network of community activists and radicalized dropouts, focused upon the squats and communes of depopulating and déclassé suburbs like Notting Hill, Stepney, Stoke Newington and Moss Side, the four met and lived across London and later Manchester, attempting to establish a legal aid centre there, but continuing to drift inconsequentially. ${ }^{59}$

Barker had some success with his community activism in Notting Hill, a politically-charged area of London full of squats, social centres, black radicalism, and site of 'King Mob', a radical association of English artists originally affiliated with the French Situationists. ${ }^{60}$ He helped establish the West London Claimants' Union, which in his later trial he referred to as 'the most important thing I've ever done' (a further 82 claimants' unions were established across the UK by late 1972), and undertook an unfinished sociological investigation into property speculation, private security and concentration of wealth in the area ${ }^{61}$ These diverse connections cross-fertilized, reflecting the wider gamut of new political commitments, cultural forms and social movements that were germinating out of the counterculture from 1969.

Barker read French, as did the members of King Mob, and was influenced by the revolutionary libertarianism of the Situationists, via Guy Debord's The Society of the Spectacle and Raoul Vaneigem's The Revolution of Everyday Life, both published in 1967. Though a loosely-lit grouping dogged by factional disputes, their ideas had been influential for the young protesting enragés during May 1968 in Paris, which Barker 
and Mendleson attended, and gained further application in the underground press. ${ }^{62}$ Their fusion of existential alienation with anarchist politics reflected the mood of the counterculture, corresponding to the analyses of Marcuse and Fromm. As Debord put it, 'commodities are now all that there is to see; the world we see is the world of the commodity', a repressive, socially-engineered 'spectacle', where piecemeal attempts at reform, through existing hierarchies like trade unions or mainstream political parties, were bound to end in failure. ${ }^{63}$

References to the 'spectacle' of capitalist consumer society were found in the first communiqué of the Angry Brigade, as well as the pamphlet Why Miss World? produced by feminist protesters who disrupted the Miss World Contest of $1970 .{ }^{64}$ Indeed between 1970 and 1971, Barker wrote a 'Daily Grind' supplement to IT, and he and Creek worked on two issues of Manchester's Mole Express, while Greenfield and Mendleson wrote several pieces for Liverpool's Strike!; Creek would also work with Angela Weir to put together a "Women's Issue" of Frendz magazine in February 1971. ${ }^{65}$ The dispersal of disenfranchised young people into the counterculture, politicised by the existential and internationalist preoccupations of the earlier New Left, in turn led to a growing political radicalism in the underground press.

Whilst the counterculture was becoming increasingly politically active from 1969 , police and judicial censure were also beginning to pique, reinforcing a mood of repression. Protests by Cambridge students against the Greek military junta in February 1970 culminated in a riot at the Garden House Hotel. Eight students were given harsh custodial sentences by Justice Melford Stevenson, prompting a media debate over political violence and appropriate punishment. ${ }^{66}$ The heavy sentences were reflected the 
inherently pessimistic discourses of political violence that had taken place following the March 1968 VSC march, and a feeling in the radicalized counterculture of being victimized by unfair police violence was reinforced in the underground press following the Mangrove Trial and Oz Obscenity trials of $1971 .^{67}$

Jagger's throwaway line, 'we're violently frustrated', reflected the growing frequency of political violence in Britain from 1968. A terrorist campaign of kidnappings, bombs and machine gun attacks by the Spanish anarchist and anti-Franco First of May group had begun on 1 April 1967 against the Spanish Embassy in London, with a further attack on 20 August $1967 .{ }^{68}$ Whilst the initial perpetrators were probably Spanish exiles, the campaign resumed on 3 February 1969, when unexploded bombs were discovered outside a Spanish bank in London. English students were caught and imprisoned for involvement, suggesting - as Gordon Carr has also argued - that a small number of students had been recruited by the Spanish group. ${ }^{69}$

From 1969 a number of small fire-bomb attacks were carried out, usually unclaimed, against targets initially related to Northern Ireland and British army involvement. The home of Duncan Sandys, Home Office minister, was attacked on 16 August, and the Ulster Office was fire-bombed the following day. ${ }^{70}$ Small firebomb attacks became frequent in 1970 within London, with Spanish targets (often Iberian Airlines, or the Spanish Embassy); various branches of Barclays Bank; local Conservative Associations; army recruitment and training offices; Lambeth court, Paddington police station; army depots and similar property-targets each being slightly damaged in these unclaimed attacks. ${ }^{71}$ Simultaneously, the underground press continued to gesture towards more violent forms of protest: IT's 20 November 1970 issue 
reproduced excerpts of Brazilian revolutionary Carlos Marighella's Minimanual of the Urban Guerrilla, with the vague endorsement that 'his methods can be re-interpreted to the British situation' ${ }^{72}$ Violence had become increasingly raised, and in the process legitimised, as the only option left for a generation angry and violently frustrated.

\section{V}

Speculating on membership of the Angry Brigade is necessarily impossible for a number of reasons. Between the machine-gunning of the Spanish Embassy in London on $4^{\text {th }}$ December 1970 (the first attack claimed shortly after by signed communiqué), and the conclusion of the trial of the 'Stoke Newington Eight' on $6^{\text {th }}$ December 1972, there were ten attacks claimed by the 'Angry Brigade' across fourteen communiqués mostly sent to the underground press. Yet these communiqués also claimed connection to around sixteen separate attacks which had largely gone unreported, whilst Gordon Carr's BBC documentary research has attributed Angry Brigade responsibility to a string of attacks against British army targets to which no communiqué survives, and to which no other evidence reinforces. ${ }^{73}$ Though some communiqués share similar wording and a common print stamp, they were also written in different styles suggesting different authors. ${ }^{74}$

More confusingly, the Angry Brigade would claim responsibility for attacks previously claimed by groups with equally mischievous names like 'Butch Cassidy and the Sundance Kid' and 'the Wild Bunch', ${ }^{75}$ whilst at trial they were charged for a wider set of attacks based on a similar explosive technique which no 'member' had claimed responsibility for (the bombing of Paddington Police Station on 22 May 1970 was later 
claimed by prosecutors as the Angry Brigade's first attack). ${ }^{76}$ The five eventually prosecuted were only sentenced for conspiracy and not actual involvement in planting explosives. There is sufficient reason to accept the claim made in several communiqués that the group was largely incoherent, composed of disorganised groups of individuals without contact: 'we are too many to know each other ... We are not in a position to say whether any one person is or isn't a member of the Brigade' ${ }^{77}$ This made the work of police investigators (and subsequent historians) somewhat difficult.

However it is possible to make some inferences from events that suggest its composition and connection to the counterculture. In the only comprehensive history of the Angry Brigade, Gordon Carr argues that the gelignite and machine guns later used in the attacks would have probably come via the anti-Francoist First of May group. There is good evidence for this hypothesis: Spanish airlines and embassies were frequently attacked in 1970, and usually several weeks before an unrelated firebomb or bomb attack related to British political protests. ${ }^{78}$ If Barker and Greenfield were responsible for carrying out the explosions, then this contact was probably facilitated by Stuart Christie, who they met in February 1970 in Stoke Newington. ${ }^{79}$ Christie was an anarchist with substantial links to the First of May Group and had been imprisoned in Spain from 1964 to 1967 for attempting to assassinate Franco. Indeed the first attack claimed by the 'Angry Brigade' was the machine-gunning of the Spanish Embassy on 4 December 1970, claimed in two separate communiqués dispatched to IT, the lengthier of which made it into their 17 December issue. ${ }^{80}$ 'The Angry Brigade doesn't claim responsibility for everything. We can make ourselves heard in one way or another. We 
machine gunned the Spanish Embassy last night in solidarity with our Basque brothers and sisters. ${ }^{, 81}$

The choice of issuing a 'communiqué' imitated the Weather Underground in the US, a radicalised offshoot of the Students for a Democratic Society, who issued their first as a warning to attack major national targets on 21 May 1970 following a series of violent attacks the previous year. ${ }^{82}$ Alongside growing violence in the US and the UK, from November 1969 there was a bombing campaign by Tupamaros-West Berlin and Tupamaros-Munich in West Germany, with bank robberies by the newly-formed RAF from September $1970 .{ }^{83}$ Despite being in diverse locations and without shared contacts, a small minority of radicalized students who had previously been involved in antiVietnam protests, led largely by New Left-orientated political groups, were each taking up direct action out of frustration with existing forms of peaceful protests and parliamentary politics. As the West German RAF wrote in April 1971, 'We will not talk about "armed propaganda": we will do it' ${ }^{84}$ In justifications of terrorism made by the RAF, abstract comparisons were made to the perceived systemic violence of the state (what the RAF called 'bourgeois violence'), against a 'revolutionary violence' or what Marighella had called 'counterviolence' as a legitimate opposition. ${ }^{85}$

The RAF, Weather Underground and Angry Brigade would each draw on oversimplified comparisons to international independence or civil rights struggles to justify their tactics. As the Stoke Newington Eight Defence Committee later put it, indicating the kinds of justifications for violence that would have occurred among the Angry Brigade at this time, 'Planting bombs is just one form of illegal direct action among many others'. ${ }^{86}$ 
Whilst the Angry Brigade initially complained that information was being 'suppressed by the bourgeois press', one possible motivation for this new kind of protest strategy is indicated by Creek, interviewed later in 2002. For her, the bombs had the more innocent intention of exposing the vulnerability of the system and amplifying existing protest movements. ${ }^{87}$ This would indicate connections to women's liberation and Situationist critiques in the choice of initial attacks, as well as the nature of their subsequent targets, which related more immediately to the industrial disputes that were already dogging the Heath government.

Heath's minister for employment, Robert Carr, had been charged with the difficult task of converting Heath's combative anti-union election promises into workable policy. The Industrial Relations Bill devised and published on 3 December 1970 sought to legally restrict unions and industrial actions, curbing wild-cat strikes, removing unions' legal immunity against employers during strikes, and rendering solidarity strikes illegal. ${ }^{88}$ The bill was antagonistic and immediately unpopular with the TUC. Major national demonstrations against the bill on 8 December were followed by a mostly-unreported bomb attack against the Department of Employment and Productivity, which the Angry Brigade claimed in communiqués 2 and $3 .{ }^{89}$ Discouraged by the lack of coverage, a second day of national protests to 'Kill the Bill' on 12 January 1971 were followed by two bomb explosions outside the home of Robert Carr. It was the most ambitious attack by the Angry Brigade so far (and, in its short life, superseded in media coverage only by the later trial of the 'Stoke Newington Eight'), and various communiqués dispatched to The Times, The Guardian and The Daily Mirror secured the attention of the establishment: 'Robert Carr got it tonight. We're getting closer.'90 
Intensive police attention into the counterculture also got closer. The audacious targeting of a government minister quickly led to a heavy-handed police investigation that seemed to consider the entirety of the British counterculture as potential suspects. Between January and August 1971 it carried out thirty nine raids, including the underground press (the offices of IT and Time Out), New Left groups (International Socialists, Agit-Prop, the Notting Hill People's Association) and associated individuals. ${ }^{91}$ Following the bomb attack against the Scotland Yard Computer Room in July, a new 'Bomb Squad' was established under an anonymous 'Commander X', combining CID, Special Branch and Explosives officers, with around 20-30 staff. According to the Sunday Telegraph, the Bomb Squad would take a tougher line, targeting and criminally investigating the entire counterculture: 'It will raid hippy communes, question avowed members of the 'underground' and build up a complete file on the sub-culture that threatens the social order'. ${ }^{92}$ Many complained of unfair harassment, which for a time solidified the counterculture into sympathy, but gradually led to uneasiness. ${ }^{93}$

The explosions outside Carr's home did not affect the passage of the Industrial Relations Bill, which despite further TUC protests made it into law by August 1971. Despite the optimistic call of their fifth communiqué, there had been no popular movement in support or mainstream political defence of their choice of targets or strategy. The confusing variety of targets chosen by the Angry Brigade, alongside their lack of connection to any organised political party exacerbated their isolation. Their subsequent targets were too broad to be classified into one political position: Ford's Essex office during an industrial dispute (18 March); the Biba fashion boutique during a 
shop assistants' pay dispute (1 May); the Scotland Yard Computer Room (22 May); the home of Ford's managing director, William Batty, and a transformer at its Dagenham factory, during another labour dispute (22 July); the home of Heath's minister for Trade and Industry, John Davies (31 July); a London army recruitment centre (15 August); and the home of Chris Bryant, during a labour dispute (20 October). ${ }^{94}$ Each indicates a general political commitment to workers' rights, opposition to the presence of British soldiers in Northern Ireland, and opposition to surveillance and consumerism. Yet the increasingly lengthy communiqués issued by the Angry Brigade were unable to foster sympathy, or understanding, beyond the sympathetic fringes of the counterculture.

Reaction was damning in the mainstream press following the Carr bombs, with suspicion of a new 'imported terrorism' on the rampage. The Daily Mirror led the charge, offering a $£ 10,000$ reward for any information leading to a prosecution of those who had delivered 'a sinister invitation to the British people to endure or condone the sick society which has afflicted the United States' ${ }^{95}$ There were anxieties that a new political violence had infected the counterculture, acquired from abroad and a threat to the British way of life. Carr himself erred on the side of caution, speaking in a BBC radio interview the following morning, 'if it were done by anybody as part of a protest I am sure they are extremists and a tiny minority indeed'. ${ }^{96}$ Yet media discourses increasingly equivocated political violence with the wider counterculture and politics of the New Left, alienating even potential allies. Lynne Segal argued that the Angry Brigade pointed to a 'more macho, warlike, paranoid and desperate politics', serving little political purpose: 'Illegality became not so much an act to fight and expose the class basis of bourgeois law, as a necessary thrill., 97 
Whilst the Angry Brigade increasingly depended on the underground press for sympathetic coverage of their attacks, the anarchist politics they expressed, with a call for a more total revolution, also brought them into conflict with any other political allies on the Left. 'There is a certain kind of professional who claims to represent us', they claimed, 'the MPs, the Communist Party, the Union leaders, the Social Workers, the old-old left ... THEY always sell us out' ${ }^{98}$ Whilst it reflected a wider countercultural distancing from the institutionalized parliamentary politics of the 'old-old left', it prevented building links with more popular and organised political movements. This dissatisfaction with mainstream politics, and even community activism and social movements, is mirrored in their sixth communiqué, which rejected 'concentrating on 'issues' or ... watered down socialist platitudes' ${ }^{99}$ Beneath the rhetoric of workers power and revolution in their missives was a deeper pessimism that any other kind of peaceful political change was now ultimately ineffective.

After a rapid series of police raids, Jake Prescott was the first to be charged on 13 February, followed by Ian Purdie on 7 March (previously imprisoned for the firebombing of the Ulster Office in 1969). ${ }^{100}$ Whilst the police investigation made little progress through political leads, it was through a more straightforwardly criminal investigation into cheque fraud that Prescott and Purdie would become linked to Mendleson, and Greenfield, with their Stoke Newington home, shared with Creek and Barker, raided on 20 August. A cache of explosives and machine guns were 'found' during the raid (the defence would later make a credible argument that these were planted), with the four being arrested that day, and Stuart Christie and Chris Bott arrested whilst visiting the property the following day. Further Angry Brigade-claimed 
attacks continued, and four individuals were arrested in raids in the following weeks, with Kate McLean and Angela Weir being ultimately charged as part of the final 'Stoke Newington Eight'. The punitive jail sentence of fifteen years that Prescott was sentenced on 1 December 1971 (simply on 'conspiracy' linking his handwriting to addresses on three envelopes), a changing political mood against further violence, exacerbated by the lethal explosions by the IRA, and the vast work now being put into the defence of the Eight, three of whom (Creek, Barker and Mendleson) were defending themselves, would explain the cessation of attacks by the Angry Brigade after this point.

\section{VI}

The trial of the 'Stoke Newington Eight' began at the Old Bailey on 30 May 1972 and ended on 6 December 1972. In the course of three million words of transcripts, and 688 exhibits, the case effectively hinged on whether the prosecution could prove that the explosives found at Amhurst Road belonged to the eight and had not been planted by police. It would become the longest criminal trial of its kind in British legal history to date, ${ }^{101}$ and marked the first time that potential jurors were vetted by the defence, to reduce any potential prejudice related to the Angry Brigade's choice of targets, a leniency overseen by Mr Justice James. ${ }^{102}$

Barker reported feeling a sense of relief once the trial began, allowing them the opportunity to explain their case to a public audience. 'It is not so disrespectful to see the trial as one of the few achievements of the Angry Brigade', he later reflected, 'and this was so because it was no longer clandestine'. ${ }^{103}$ The trial was extensively covered by both the underground and mainstream press across 1972, and may indeed have 
introduced the ideas of the Angry Brigade to the public. ${ }^{104}$ Internal BBC documents of its Review Board reveal consternation over the apparently-lax 'error of editorial judgement' which enabled the Angry Brigade to broadcast their opinions on Radio Four's World at One, as well as earlier coverage of the Carr bombing. ${ }^{105}$

The trial provided an opportunity to discuss the justification of violence that began in the underground press, and which remained in discussion following the 1971 publication of William Powell's quasi-mythical Anarchist Cookbook. ${ }^{106}$ As a justificatory pamphlet for the Stoke Newington Eight defence group put it, 'It's apparently O.K. to squat, attack police on a demo, hurl CS gas canister in the House of Commons, picket, occupy, etc. But as soon as you use a bomb (even against property solely) you forfeit, it seems, your identity as a socialist. ${ }^{107}$ Yet the defence of political violence ran counter to a general awkwardness or open rejection of it from it among the counterculture. The loss of life caused by political violence by international groups with a revolutionary socialist politics to the Angry Brigade ran counter to earlier beliefs in cooperation and peace, to the point that such a politics became associated with lethal violence. After the brief optimism of the Tet Offensive, there was little expressed belief that the RAF, Weather Underground, Red Brigades or the Angries had any possibility of 'winning'. Cautious admiration for the self-determination of the Stoke Newington Eight subsided, but no similar left-wing armed campaign was undertaken in the UK the years following the demise of the Angry Brigade.

For others, the experience of assisting the defence of the Stoke Newington Eight was contradictory and disquieting. As Elizabeth Wilson put it, it was a 'crash course in political reality': on the one hand, it underlined the realness of the state's repressive 
power, and on the other, was a disenchanting lesson that political action could only be effective by working with 'mainstream organizations of the working class and of the progressive movement', such as political parties and trade unions. ${ }^{108}$ The exhausting length of the trial and the negative media coverage around it placed an uncomfortable spotlight on the otherness and perversity of the counterculture. Against Barker's optimism, attitudes came to the fore that seemed to reverse the aims of activists in the new social movements. Newspaper coverage became increasingly obsessed with the identity and sexuality of the two female self-defendants, Creek and Mendleson. As the Express reported, 'Typical of the petticoat Violent Ones was dark-haired, bosomy Anna Mendleson, recruited from the discontents at Essex University, Colchester'. ${ }^{109}$ Whilst spurious stories abounded in the Colchester Gazette of 'cottage orgies', ${ }^{110}$ the media began to transform Mendleson into some sort of underground 'pin-up', the very sexual caricature the Angry Brigade were trying to shatter.

By the time of the eventual sentencing of the Stoke Newington Eight on 6 December 1972 (resulting in ten-year prison sentences for Mendleson, Creek, Barker and Greenfield), the negative image of the counterculture was complete. ${ }^{111}$ The News of the World warned of a possible violent backlash from the counterculture. Next to the sub-heading, '200 at large still have chance to kill', was reported 'Commander Bond's band brought some of them to justice. There are many more. One saw them at the trial hairy ones, watching, scribbling, plotting'. ${ }^{112}$ The trial of the Stoke Newington Eight if anything brought the otherness of the counterculture into the public spotlight. With their long hair, unusual ideas, drug-taking and permissive sexual mores, negative perceptions of the counterculture floated back into the public domain. The Sun's headline, 
"Downfall of the Bighead Brigade", communicated an aloofness to their actions which has largely stuck, with popular memory being unsure of what the Angry Brigade stood for. ${ }^{113}$ Angry Brigade communiqués were quoted alongside dismissive jibes: 'looney plots' (The Sun), 'revolutionary claptrap' (News of the World), or 'bomb-happy destructionists' (Daily Express). ${ }^{114}$

The Angry Brigade's actions were also repeatedly and explicitly linked to the student protest movement and university education. Justice James blamed 'a warped understanding of sociology' in his sentencing, ${ }^{115}$ whilst J.C. Gunn of the Institute of Psychology argued that they had been 'affected by their exposure to university life'. ${ }^{116}$ The Evening Standard collapsed the entire student movement, counterculture and more moderate trade unionists into the simplified category of violence: these 'guerrillas are the violent activists of a revolution comprising workers, students, trade unionists, homosexuals, unemployed and women striving for liberation. They are all angry. ${ }^{117}$

Yet for all the triumphalist rhetoric on either side, the trial itself was peculiarly inconclusive. Though Barker, Creek, Greenfield and Mendleson were found guilty for conspiracy to cause the explosions (like Prescott), no-one was found guilty for causing the explosions themselves. Similarly whilst the jury rejected the defence's claim that explosives had been planted, their decision to acquit Stuart Christie, in whose car detonators were also 'found' by police investigators, logically suggests that these must have been placed there by someone other than Christie. The overall verdicts were inconsistent, and beneath the surety of jail sentences is a wider ambiguity consistent with later Bomb Squad-led prosecutions of the 'Guildford Four', 'Maguire Seven' and 'Birmingham Six', subsequently repealed following inconsistencies in forensic evidence 
and police testimony. ${ }^{118}$ As Jackie Leishman wrote in the Guardian following the trial, 'at the end of it all, we are still no clearer about what the Angry Brigade really is, how it is organized, what its aims are - or whether it is still in being. ${ }^{, 19}$ This remains true today.

\section{VII}

Rather than devote overt attention to the five individuals prosecuted for conspiracy, as Carr has done, or lionizing the particular achievements of the Angry Brigade, as punk historian Tom Vague does, I would suggest that the name 'Angry Brigade' might be better understood as a moniker adopted by a wider number of individuals for a broader set of illegal attacks against political targets. This would explain the wide number of attacks claimed by 'the Angry Brigade' accompanied with the characteristic stamp of the communiqués, alongside the far greater number of amateur explosions that did not. Stuart Christie, probably familiar with individuals behind these attacks, casts doubt on the homogeneity of a singular group: 'It seemed that ... a lot of the left who wanted to participate in what was clearly a revolt against conformism and the accepted rules of the political game were joining in: manifestos accompanied fresh attacks but they were not necessarily coming from the same people. ${ }^{120}$ As Christie put it earlier, the police were 'trying to find an organisation that did not exist'. As Barker puts it, they 'framed a guilty man'. ${ }^{121}$

Neither Barker, Creek nor Prescott have claimed a positive legacy for the bombings. Barker repeatedly found it 'painful' and 'cringe'-worthy looking back on their actions, whilst Prescott, recipient of the longest jail sentence, later wrote to Robert 
Carr to apologize for his limited role. ${ }^{122}$ They have highlighted instead the value of their community work, be it in the Claimants' Union for Barker, the early women's movement for Creek, or the citizens' advice bureau for Prescott in later life. As Mendleson answered in an interview with Granada TV's 'World in Action' after the trial, 'achievement, in terms of change, it hasn't achieved anything, anything at all'. ${ }^{123}$ The actions of the Angry Brigade perhaps marked this transition with their exhortations of 'class war', yet even they themselves were of the 1968 era and remain 'little remembered' by popular history now. ${ }^{124}$

The lasting verdict of the Angry Brigade by the counterculture and the New Left tends to be sympathetic of its idealism, but ultimately scathing. For Fountain, the Angry Brigade's attacks 'chilled the political atmosphere', a 'suicidal diversion' which 'one way or another, would be crushed by the power of the state'. ${ }^{125}$ For Stuart Hall, the activities and subsequent defence of the Angry Brigade may have had good intentions in 'bringing the war back home' by attempting to link working class and anti-imperialist struggles in a wider struggle against capitalism. ${ }^{126}$ Ultimately though, it was a 'tragic affair' that led 'unwittingly' to a more repressive political climate for the counterculture and the new social movements. ${ }^{127}$ Worse, it encouraged ordinary workers to view the New Left movements not as allies but as a threat, with terrorist violence a 'self-fulfilling prophecy' and its inevitable outcome, seemingly proving that 'a violent conspiracy against the state $d i d$ exist, and was located in or near the mass disaffiliation of youth'. ${ }^{128}$ Barker writes that whilst 'we were libertarian communists believing in the mass movement', at the same time 'we were not that serious....like many young people then and now we smoked a lot of dope and spent a lot of time having a good time'. ${ }^{129}$ Such 
irreverence may be misleading, especially to critics like Hall, Segal or Fountain, who argue that the events around the Angry Brigade accelerated the criminalisation and dispersal of the counterculture. But it reflects the incoherency of a dispersed, looselyassociated network of radicalized young people who, between 1967 and 1972, comprised many angry brigades. They were among an impassioned, self-aware 'generation' that felt determined and optimistic enough to dismantle the authoritarian structures that had led to world wars, genocides, and colonial oppression. Despite enjoying greater political freedoms than any previous generation in the modern industrialised West, many felt more oppressed, and more motivated to do something about it, than their parents had before. The Angry Brigade also marked a growing disengagement with mainstream political parties, media, and trade unions, reflecting a more theoretical, less totalizing and more identity-focused politics that would continue across the 1970s, as the fissures between New and Old Left deepened. Those intellectuals without a party would increasingly lost their connection with the growing union militancy and strikes that would devastate the legitimacy of Heath's government by 1973, without explosives.

The Angry Brigade also mark the threshold between the amateur and largelyabortive fire-bombings of various British army, Conservative and Ulster-related targets, and the far more devastating campaigns of the Official, and Provisional, IRA from 1972 on, matched by a cohesive political campaign led by Sinn Fein with a more coherent set of grievances and local support. Being not that serious distinguished the approach of the 'Angries', and perhaps unwittingly aided many from not being prosecuted or receiving longer sentences. 'No revolution was ever won without violence', they claimed on 19 
February $1971 .{ }^{130}$ Lacking popular support or an organized popular movement behind them, the Angry Brigade offered violence without the possibility of revolution. While the party may have been over, the Angry Brigade were a brief, abortive, vanguardist and yet 'not that serious' nebula of British countercultural dissent and revolutionary political violence. Whilst it failed in its expressed goals and left little lasting impression on contemporaries, its rise and demise offers an illuminating case from which to survey changing concepts and forms of political opposition and violence in Britain between 1967 and 1972.

Department of Humanities, Digby Stuart College, University of Roehampton, London SW15 5PH. Taylord2@roehampton.ac.uk.

1 See for instance Arthur Marwick, British Society Since 1945 (London, 2003), p. 147; Roy Porter, London: A Social History (London: Penguin, 1996), pp. 362-363; Peter Clarke, Hope and Glory: Britain 1900-1990 (London, 1997), pp. 290-292; Jerry White, London in the Twentieth Century: A City and Its People (London, 2002), pp. 341-351. For a refreshingly critical take on these two decades, though again lacking analysis of political violence, see Kenneth O. Morgan, Britain Since 1945: The People's Peace (New York: Oxford University Press, 2001), pp. 261-262, 294-297.

2 Dominic Sandbrook, White Heat: A History of Britain in the Swinging Sixties (London, 2006), p. xi.

3 Jonathon Green, All Dressed Up: The Sixties and the Counterculture (London, 1999), p. xii; Tariq Ali and Susan Watkins, 1968: Marching in the Streets (New York, 1998), p. 10.

4 Based on a quantitative study of targets referred to in their fourteen communiqués issued to the underground and national press. Note that the originals of these communiqués no longer survive, and historians are necessarily dependent on either archives of the underground press which quote them, or Carr's comprehensive account of the Angry Brigade, based on an initial 1973 BBC documentary and later published in 1975 (republished 2003 and 2010). See Gordon Carr, The Angry Brigade: A History of Britain's First Urban Guerrilla Group (Oakland, 2010), pp. 237-248.

5 Stuart Christie provides an exhaustive chronology in Carr, Angry Brigade, pp. 194-237. 
6 Marwick devotes more significance to the Garden House Hotel protest in Cambridge: see Arthur Marwick. The Sixties: Cultural Revolution in Britain, France, Italy, and the United States, c.1958c.1974 (New York, 1998), pp. 751-752. Its absence is conspicuous in Jeremy Black's discussion of Britain as 'ungovernable' in Chapter 4 of Britain Since the Seventies (London, 2004); I refer also to Andy Beckett, When the Lights Went Out: Britain in the Seventies (London, 2009); Clarke, Hope and Glory; Morgan, Britain Since 1945; Porter, London: A Social History; White, London in the Twentieth Century.

7 Tom Vague, Anarchy in the UK: The Angry Brigade (Edinburgh, 1997); Green, All Dressed Up, pp. $272-292$.

8 Tim Pat Coogan, The IRA (New York, 2002), pp. 385-386.

9 Jeremy Varon, Bringing the War Home: The Weather Underground, the Red Army Faction, and Revolutionary Violence in the Sixties and Seventies (Berkeley, 2004), pp. 4-5; Samantha M. R. Christiansen, ““'The Brigade is Everywhere”: Violence and Spectacle in the British Counterculture”, in Timothy Brown and Lorena Anton (eds.), Between the Avant-garde and the everyday: subversive politics in Europe from 1957 to present (Bergahn, 2013), pp. 48-49.

10 Christiansen, "The Brigade is Everywhere", p. 57; Lucy Robinson, "Carnival of the Oppressed: The Angry Brigade and the Gay Liberation Front", University of Sussex Journal of Contemporary History, Issue 6, August 2003, pp. 4-8.

11 A feeling evoked by contemporaries, and used directly by Sheila Rowbotham, Promise of a Dream: Remembering the Sixties (New York, 2001), p. 205.

12 Stuart Hall, "Life and Times of the First New Left", New Left Review, 61 (Jan-Feb 2010), pp. 177178.

13 Hall, "Life and Times", p. 178; Geoff Andrews, "The Three New Lefts and their Legacies", in Geoff Andrews et al. (eds), New Left, New Right and Beyond: Taking the Sixties Seriously (Basingstoke, 1999), pp. 67-68.

14 I have also drawn broadly on three histories of the British New Left: Michael Kenny, The First New Left - British Intellectuals After Stalin (London, 1995), Lin Chun, The British New Left (Edinburgh, 
1993); Dennis Dworkin, Cultural Marxism in Postwar Britain - History, the New Left, and the

Origins of Cultural Studies (Durham \& London, 1997).

15 E.P. Thompson, "Socialist Humanism: An Epistle to the Philistines”, New Reasoner, No. 1, Summer 1957, pp. 105-143; and in response, Charles Taylor, “Marxism and Humanism”, New Reasoner, No. 2, Autumn 1957, pp. 92-98. Discussion would continue in subsequent issues.

16 Alan Hooper, “A Politics Adequate to the Age: the New Left and the Long Sixties", pp. 16-19; Tom Steele, "Hey Jimmy! The Legacy of Gramsci in British Cultural Politics", p. 31; Andrews, "The Three New Lefts and their Legacies", pp. 68, 75 - in Andrews, New Left, New Right and Beyond.

17 Steele, "Hey Jimmy!", New Left, New Right and Beyond, pp . 32-34.

18 Nigel Fountain, Underground: The London Alternative Press, 1966-74 (London, New York, 1988).

19 Barker, "Review of Tom Vague's 'Anarchy in the UK: The Angry Brigade"' in Carr, Angry Brigade, p. 184-185.

20 Tariq Ali supplies strong evidence of its internationalist focus throughout 1968: Marching in the Streets.

21 Students for a Democratic Society, "Introduction: Agenda for a Generation", Port Huron Statement, in William S. McConnell (ed.), The Counterculture Movement of the 1960s (Farmington Mills, 2004), p. 45.

22 Jonathon Green, Days in the Life: Voices from the English Underground 1961-1971 (London, 1988),, p. vii.

23 Clarke, Hope and Glory, pp. 288-289.

24 Good biographical information is provided in Jackie Leishman, "A trial without the Angry Brigade", The Guardian, 7 December 1972, pp. 12-13.

25 Clarke, Hope and Glory, pp. 291-292.

26 Green, Days in the Life, p. 112.

27 Caroline Hoefferle, British Student Activism in the Long Sixties (New York; London, 2013), p. 102.

28 H.L. Malchow, Special Relations: The Americanization of Britain? (Stanford, 2011), chs. 3-6; Mark Donnelly, Sixties Britain: Culture, Society, and Politics (New York, Abingdon, 2005), p. 85. 
29 Theodore Roszak, The Making of a Counter Culture: Reflections on the Technocratic Society and its Youthful Opposition (London, 1970), pp. 1-7.

30 Rowbotham, Promise of a Dream, p. 225; Barry Miles, Hippie (London, 2003), p. 330.

31 Carol Hanisch, "The Personal is Political", in Shulamith Firestone \& Anne Koedt (eds), Notes from the Second Year: Women's Liberation (New York, 1970), pp. 76-78; Fountain, Underground, pp. 4950; Hooper, "A Politics Adequate to the Age", in Andrews, New Left, New Right and Beyond, pp. 1618; Carr, Angry Brigade, p. 23.

32 Ibid. pp. 291-2; White, London in the Twentieth Century, pp. 341-343; Bob Dickinson, Imprinting the Sticks: The Alternative Press Beyond London (Aldershot, 1997), p. 59.

33 Clarke, Hope and Glory, pp. 317-318; Morgan, Britain Since 1945, pp. 262-263.

34 Peter Townsend and Dorothy Wedderburn, The Aged in the Welfare State (London, 1965); Brian Abel-Smith and Peter Townsend, The Poor and the Poorest (London, 1965).

35 Fountain, Underground, p. 188. This mood of pessimism within the establishment would continue into the 1970s, reflected in Frank Kitson's British counter-terrorist work, Low Intensity Operations (1971), Alan Burns' The Angry Brigade and B.S. Johnson's Christie Malry's Own Double-Entry (both 1973), whose plots revolve around terrorist campaigns; and Anthony Burgess's anti-TUC pessimistic prophecy, 1985 (1978).

36 Morgan, Britain Since 1945, pp. 288-289, 300-305.

37 Time Out, 13 June 1970, quoted in Chad Andrew Martin, Paradise Now: Youth Politics and the British Counterculture, 1958-1974 (PhD Thesis, Stanford University, 2003), p. 282.

38 Hoefferle, British Student Activism, pp. 109-115.

39 Malchow, Special Relations, pp. 52-63.

40 Carr, Angry Brigade, pp. 199, 208.

41 Ibid. pp. 29-32; Fountain, Underground, p. 53.

42 Fountain, Underground, p. 61.

43 Ibid. pp. 56-60.

44 Hoefferle, British Student Activism, pp. 110-111; “Sauce Box”, IT, Vol. 1, No. 28, 5 April 1968, p. 2. 
45 "Jagger/Miles", IT, vol. 1, no. 31, 17 May 1968, p. 3; Fountain, Underground, p. 38; Tariq Ali, Street

Fighting Years: An Autobiography of the Sixties (London, 2005), p. 300.

46 New Society, 21 March 1968, in Carr, Angry Brigade, p. 205.

47 White, London in the Twentieth Century, pp. 205, 349-50.

48 Martin, Paradise Now, p. 280.

49 Donnelly, Sixties Britain, pp. 148-150.

50 Dickinson, Imprinting the Sticks, p. 54.

51 Barker in Carr, Angry Brigade, p. 32.

52 Malchow, Special Relations, pp. 62-63.

53 See for instance Rowbotham on the schisms within Black Dwarf: Promise of a Dream, p. 250.

54 Ibid. p. 206.

55 Dworkin, Cultural Marxism in Postwar Britain, p. 193.

56 Fountain, Underground, pp. 124-5; Dickinson, Imprinting the Sticks, p. 69.

57 Leishman, "A trial without the Angry Brigade”, p. 12.

58 Green, Days in the Life, p. 358.

59 The Guardian [editorial], “Angry Brigade: Revolutionary Pollyannas”, 7 December 1972, p. 16.

60 Timothy Scott Brown, "The Sixties in the City: Avant-gardes and Urban Rebels in New York, London, and West Germany", Journal of Social History, vol. 46, no. 4, summer 2013, pp. 830-834.

61 John Windsor, "Defendant tells of meeting members of the Angry Brigade", The Guardian, 14

October 1972.

62 IT featured a Situationist-inspired cover on its 16 February 1969 issue, originally fly-posted on their office; Carr, Angry Brigade, pp. 19.

63 Guy Debord, The Society of the Spectacle, trans. Donald Nicholson-Smith (New York, 1995), II §42, p. 29.

64 Weir, "Introduction", Angry Brigade 1967-84, p. 21.

65 John Friendly, "The Daily Grind”, IT, vol. I, no. 84, 30 July 1970, pp. 7-10; Fountain, Underground, pp. $57,154,162-3$.

66 Carr, Angry Brigade, pp. 54. 
67 White, London in the Twentieth Century, pp. 296-297; Mike Phillips \& Trevor Phillips, Windrush: The Irresistible Rise of Multiracial Britain (London, 1998), pp. 277-280.

68 Carr, Angry Brigade, pp. 47, 199. The First of May group were a geographically dispersed network, targeting symbols of Spanish authority in other European cities, including Paris, Turin, The Hague, and Bonn.

69 Ibid. pp. 45-59.

70 Ibid. p. 212.

71 Evidence of these obscure attacks has again been exhaustively collated by Stuart Christie, and appended to Carr's documentary history of the group. See Carr, Angry Brigade, p. 214-218.

72 “Street Fighting Man”, IT, vol. 1, issue 92, 20 November 1970, p. 8.

73 Including a BBC broadcast van at the Miss World 1970; two attacks on the home of Attorney General Rawlinson; the home of Metropolitan Police Commissioner Waldron; four Barclays' branches; six Conservative associations; and a generator in Altrincham, all undated. See 'first communiqué', communiqués 5 and 7, and Christie's timeline of later 'Angry Brigade' attacks, in Carr, Angry Brigade, pp. 226, 237, 239, 241-243.

74 Most end with 'power to the people' or 'revolution', and there are frequent addresses to 'brothers and sisters' and 'comrades' in many, though these were fairly common forms of address. The exuberance and frequently capitalized phrases of seven and eight (again of a style similar to a typical article in the underground press) are dissimilar to the paranoid cautiousness of six, the violent threats of twelve, or the calm eloquence of five, six and thirteen. See Carr, Angry Brigade, pp. 237-248.

75 Ibid. pp. 50-55.

76 Ibid. p. 215.

77 Communiqué 13, in Carr, Angry Brigade, p. 248.

78 Such as the 18 August 1970 bombing of Iberian Airlines in London, and the attack on the home of Waldron claimed by 'Butch Cassidy' and 'the Sundance Kid' twelve days later. See Carr, Angry Brigade, pp. 51-53 for further investigation of these links.

79 Ibid. pp. 45-46; Stuart Christie, The Christie File (Sanday, 1980), p. 68.

80 Carr, Angry Brigade, p. 57. 
81 IT, Vol. 1, No. 94, 17 December 1970, p. 2.

82 Varon, Bringing the War Home, p. 120; Dan Berger, Outlaws in America: The Weather Underground and the Politics of Solidarity (Oakland, 2006), pp. 136-137.

83 Reflecting a growing internationalism, Tupamaros were named after Uruguayan Marxist rebels, and all three groups received training in a Palestine Liberation Organisation camp in Jordan. See J. Smith and André Moncourt (eds. and trans), The Red Army Faction: A Documentary History. Volume I:

Projectiles for the People (Oakland; Montreal, 2009), pp. 583-585.

84 Red Army Faction, “The Urban Guerrilla Concept", in Smith and Moncourt, Red Army Faction, p. 100.

85 RAF, “Urban Guerrilla Concept”, p. 86.

86 Stoke Newington Eight Defence Group, If You Want Peace, Prepare for War (London, 1972), p. 15.

87 Interviewed in Martin Bright, “Look Back in Anger”, The Observer, 3 February 2002.

88 On the Industrial Relations Bill of 1970, and enactment the following year, see Chris Wrigley, British Trade Unions 1945-1995 (Manchester, 1997), pp. 85-89.

89 Carr, Angry Brigade, p. 238.

90 Communiqué 4, in Carr, Angry Brigade, p. 239.

91 Ibid. pp. 94-97; Leishman, “A trial without the Angry Brigade”, p. 13.

92 Quoted in Carr, Angry Brigade, p. 224.

93 Fountain, Underground, p. 147.

94 Carr, Angry Brigade, pp. 217-226.

95 Daily Mirror, leader comment, 14.1.1971. For detailed analysis of newspaper coverage of the Angry

Brigade, see Steve Chibnall, Law-and-Order News: An Analysis of Crime Reporting in the British

Press (London, 1977), pp. 96-7.

96In Chibnall, Law-and-Order News, p. 96.

97 Lynne Segal, What is to be done about the family? (Harmondsworth, 1983), p. 49.

98 Carr, Angry Brigade, p. 241.

99 Ibid. p. 240.

100 Ibid. pp. 61, 72-78. 
101 Adam Gearey, Wayne Morrison \& Robert Jago, The Politics of the Common Law: Perspectives,

Rights, Processes, Institutions (Abingdon; New York, 2013), p. 297

102 Gary Slapper \& David Kelly, The English Legal System 2013-14. Fourteenth Edition (Abingdon;

New York, 2013), pp. 519-526.

103 Barker in Carr, Angry Brigade, p. 183.

104 Nelson, British Counter-culture, 1966-73, pp. 117-122.

105 David Hendy, Life On Air: a History of Radio Four (Oxford, 2007), pp. 93, 95, 98.

106 See for instance Jim Anderson, “The Anarchist Cookbook: ‘Turn on, Burn Down, Blow Up!”, Oz 33

(Feb/Mar., 1971).

107 Stoke Newington Eight Defence Group, If You Want Peace, p. 15.

108 Elizabeth Wilson with Angela Weir, Hidden Agendas: Theory, Politics, and Experience in the

Women's Movement (London, 1986), pp. $42-43$.

109 Daily Express, 7 December 1972, in Christie, Christie File, p. 365.

110 Fountain, Underground, p. 179.

111 Mendleson was released on parole in November 1976, and Creek in April 1977; Barker and

Greenfield were released after six years; with Prescott released after eight years: see David Pallister,

"Angry Brigade man Prescott released", The Guardian, 27 February 1979, p. 2; Carr, Angry Brigade,

p. 177.

112 News of the World, 10 December 1972, in Chibnall, Law-and-Order News, p. 112.

113 The Sun, 7 December 1972.

114 Chibnall, Law-and-Order News, pp. 110-111.

115 In Tom Vague, Anarchy in the UK, p. 114.

116 Quoted in Hoefferle, British Student Activism in the Long Sixties, p. 179.

117 Ibid. p. 179.

118 Coogan, The IRA, pp. 389-391, 517-519.

119 Leishman, "A trial without the Angry Brigade”, p. 13.

120 Christie, Christie File, p. 245.

121 Barker in Carr, Angry Brigade, p. 180. 
122 Ibid. p. 180; Creek and Prescott in Bright, "Look Back in Anger", Observer.

123 Quoted in Fountain, Underground, pp. 180, 220.

124 As put by Andrew Marr, A History of Modern Britain (London, 2007), p. 331.

125 Fountain, Underground, pp. 141, 159-160; Jonathon Green, "The Urban Guerrillas Britain Forgot", New Statesman, 27 Aug. 2001; Dickinson, Imprinting the Sticks, pp. 65-66; White, London in the Twentieth Century, p. 350.

126 Stuart Hall et al., Policing the Crisis: Mugging, the State, and Law and Order (London and Basingstoke, 1982), pp. 291-292.

127 Ibid. p. 292.

128 Ibid. p. 292.

129 Quoted in Carr, Angry Brigade, p. 184.

130 Communiqué 6, in Carr, Angry Brigade, pp. 221, 240. 